\title{
Finnish Language
}

National Cancer Institute

\section{Source}

National Cancer Institute. Finnish Language. NCI Thesaurus. Code C153919.

A Finnic language spoken by a majority of the population in Finland and by ethnic Finns outside Finland. 